\title{
Jay Gatsby’s Trauma and Psychological Loss
}

\author{
Thi Huong Giang Bui ${ }^{1}$ \\ ${ }^{1}$ Department of English Literature, Fukuoka Women's University, Japan \\ Correspondence: Thi Huong Giang Bui, Department of English Literature, Fukuoka Women's University, 1-1-1 \\ Kasumigaoka, Higashiku, Fukuoka, Japan 813-8529. Tel: 81-80-4272-2455. E-mail: bhgiang06@gmail.com
}

Received: November 28, 2012 Accepted: December 18, 2012 Online Published: January 17, 2013

doi:10.5539/ells.v3n1p42 URL: http://dx.doi.org/10.5539/ells.v3n1p42

\begin{abstract}
F. Scott Fitzgerald (1896-1940) is regarded as a great twentieth-century American novelist. In many ways Fitzgerald's legendary life has had a huge impact on critics and readers in overshadowing his great work. The 1920 s can be seen as a transition time with a great change in American history from the Victorian period to modern times and with the huge impact of World War I on people's lives. It is only recently that critics have moved away from studying Fitzgerald's work as that of a merely superficial and historical writer and examined his works in various other perspectives. In addition to historical and biographical studies, Freudian theory is an important approach to bring a new depth to our understanding of his work. In one of his great novels, The Great Gatsby, Fitzgerald depicts the traumatic losses of a self-made man, Jay Gatsby, who tries to win his idealized girl again. In this paper, the author aimed to examine the losses of Jay Gatsby in the light of Freudian theory to bring a new perspective on the protagonist's trauma and psychological loss and the reasons why he never escapes from his illusive world.
\end{abstract}

Keywords: Freudian theory, idealized love, trauma, psychological loss, illusion, fantasy

\section{Introduction}

F. Scott Fitzgerald's The Great Gatsby (1925) represents traumatic neurosis and psychological loss in the fantasy world of Jay Gatsby. It is also "an attempt to determine that concealed boundary that divides the reality from the illusion, [and] the illusions seem more real than the reality itself" (Bewley, 1954: 38). Jay Gatsby's life on Long Island offers Fitzgerald a chance to investigate psychological phenomena and the painful events expressed in relation to different characters. More specifically, at the core of Fitzgerald's The Great Gatsby, one finds perceptive insights based on Freudian theory of trauma.

The present study begins with a brief introduction to Freud's concept of trauma and then continues with a close study of Jay Gatsby. A survey of the literature concerning The Great Gatsby shows that it has been mainly approached through the frameworks of feminism, gender study, and cultural criticism, among others. However, Gatsby's loss as presented in The Great Gatsby is firmly grounded in Freudian theory of loss and trauma, not Freudian theory of infantile development, as some critics have argued. Stavola (1979) has argued that Gatsby's failure originates from the lack of moral guidance from his parents. He is "Jimmie Gatz, the son of rigidly Catholic parents, each of whom lacked a sense of personal identity as a basis for mature fulfillment" (Savola, 1979: 142). Stavola (1979) further writes, "Fitzgerald makes no mention whatsoever of Gatsby's mother and does not introduce his father until after Gatsby's death" (Savola, 1979: 133) and "in his own way Henry Gatz, who journeyed East for Gatsby's funeral, is as morally blind as his son and could not possibly have provided Gatsby with any solid moral vision" (Savola, 1979: 134).Therefore, in the present study, the first part is a brief introduction of the Freudian concept of trauma and loss to see how it helps to bring a new understanding of Jay Gatsby in The Great Gatsby. It then deals with the analysis of the novel and the extracts cited serve to document the importance of psychology of trauma. The article ends with speculation on the reason why Jay Gatsby fails and dies disillusioned with the concept of the self-made man.

\section{Freud's Concept of Trauma}

Among the major subjects treated in literature, trauma and loss as a theme or a plot device appears as one of the significant elements in the writings of novelists. In a broad sense, "the concept of trauma can be said to lie at the heart of Freud's initial discoveries and so to inform his earliest psychoanalytic formulations" (Forter, 2007: 262). Freud is regarded as a pioneer in the field of psychology in the late nineteenth and early twentieth centuries and 
his theory has had a huge impact in analyzing texts in literary criticism, and it is Freud's own analysis rather than that of recent trauma theorists that I will emphasize in this study.

In "On the Psychical Mechanism of Hysterical Phenomena: Preliminary Communication", Breuer and Freud (1893) point out "any experience which calls up distressing affects, such as those of fright, anxiety, shame or physical pain may operate as a trauma of this kind" (Breuer and Freud, 1893: 6). Furthermore, in "Beyond the Pleasure Principle", Freud (1920: 12) suggests that "traumatic neurosis" is a kind of "repetition of compulsion" of unpleasant and traumatic events. According to Luckhurst (2006: 501), "repetition compulsion has a peculiar time scheme: after the event there is an attempt to act as if in preparation before it". In other words, for the traumatized individual, the chronology is mixed in the sense that a past event repeatedly jumps into the present and then it shifts back and forth in time and place so that the traumatized person cannot realize whether it is a reality or fantasy. In "Introductory Lectures on Psycho-Analysis", Freud (1917) defines the concept of psychical reality in which fantasy and reality may coexist or can even replace each other.

Drawing from Freudian theory, the traumatic formulation relates to "an analogy between psychic and physical trauma" (Forter, 2007: 263). Furthermore, Freudian theory also argues that for a traumatized person there is a "conflict between the forces of sexuality and its repression" (Forter, 2007: 263). The sexual drives can be seen as "impulses that sought immediate and unconditional satisfaction, defined in part as the elimination of unpleasurable tension from the psychic apparatus" (Forter, 2007: 263). Breuer and Freud (1893) also point out that trauma can be derived from both irreparable loss of a loved person and the social circumstances (Breuer and Freud, 1893: 10).

Relying on Freud's notion of trauma and trying to read The Great Gatsby in the light of his theory, it can be said that Gatsby is traumatized by the loss of his idealized love. Therefore, the present paper can bring us to a significant new interpretation of Fitzgerald's novel and encourage us to read the text in a complex and vivid way.

\section{Jay Gatsby: A Traumatized Character as a Freudian Subject}

Troy (1945) points out that The Great Gatsby is Gatsby's story and "it is a story of failure-the prolongation of the adolescent incapacity to distinguish between dream and reality, between the terms demanded of life and the terms offered" (Troy, 1945: 226). However, at first, the first-person narrator, Nick Carraway, does not recognize the world of trauma and loss that Gatsby has encountered in losing his ideal love. The narrator expresses a very positive attitude toward Gatsby, about whom he thinks "if personality is unbroken series of successful gestures, then there was something gorgeous about him, some heightened sensitivity to the promises of life" (Fitzgerald, 1996:2), even though Nick had never seen Gatsby before.

Nick's prism leads the readers to believe in "an extraordinary gift for hope, a romantic readiness such as I [Nick] have never found in any person and which it is not likely I [Nick] shall ever find again" (Fitzgerald, 1996: 2, 3). On the other hand, Nick provides foreshadowing about the empty life of Gatsby immediately after expressing his opinions; for instance, when he says, "Gatsby turned out all right at the end; it is what preyed on Gatsby, what foul dust floated in the wake of his dreams that temporarily closed out my interest in the abortive sorrows and short-winded elations of men" (Fitzgerald, 1996: 3). Obviously, we know and understand Gatsby primarily through the narrator's voice, and "what Nick values in Gatsby are qualities he himself lacks: spontaneity, sensitivity outward" (Callahan, 1972: 33). It appears that Nick is also traumatized by the life of Gatsby while he recalls everything which happened to Gatsby in the past. "Nick is clearly narrating events that occurred more than two years prior to the novel's present moment, so he has had the benefit of time to reflect on and evaluate the experience" (Pelzer, 2000: 84). After more than two years thinking of what was happening both to Gatsby and himself, Nick is now jumping to the past and experiencing a personal sense of grief concerning both of them.

Gatsby encountered his first trauma when he could not keep Daisy in his life. When Gatsby first meets Daisy, he is overwhelmed by her youth, her beauty, and her wealth. However, "she [Daisy] vanished into her rich house, into her rich, full life, leaving Gatsby-nothing." (Fitzgerald, 1996: 179). Gatsby is depicted as "a penniless young man without a past" (Fitzgerald, 1996: 178) and having "no comfortable family standing behind him" (Fitzgerald, 1996: 179). Gatsby just "found her excitingly desirable" (Fitzgerald, 1996: 177) and "felt married to her, that was all" (Fitzgerald, 1996: 179). But above all, Gatsby could not give Daisy "a sense of security" (Fitzgerald, 1996: 178). For Gatsby, the definition of love is so simple, naïve and romantic, as is exemplified in his fantasy they are married. Furthermore, "it excited him, too, that many men had already loved Daisy-it increased her value in his eyes" (Fitzgerald, 1996: 178). Thus, sexual competition is also another force that makes Daisy become Gatsby's great desire. When Daisy wants her life shaped without Gatsby, he then spends all the rest of his life living with the illusions of Daisy. The day Tom and Daisy were on their wedding trip, Gatsby, after returning from war, made "a miserable but irresistible journey to Louisville on the last of his army pay" 
(Fitzgerald, 1996: 183). His thinking "that if he had searched harder, he might have found her-that he was leaving her behind" (Fitzgerald, 1996: 183) motivates him to search for Daisy for the rest of his life.

Gatsby, after five years, is rich enough to think that he can use his money to win his dream of his past because the myth of the American Dream insists that "everything of value can be bought" (Callahan, 1972: 21). In fact, Gatsby "sacrifices his life on the altar of his dream, unaware that it is composed of the ephemeral stuff of the past" (Miller, 1964: 20). Therefore, evidently, Gatsby's trauma appears when he is trapped in "a world where the promise of the past have been betrayed and the future has been grotesquely mocked" (Lehan, 1970: 112), when he tries to find his self-identity and particularly his true love from the very woman, "whom he has loved and lost" (Chase, 1957: 300). It is undoubted that "the love Gatsby has for Daisy seems to be the one pure impulse in a corrupt world" (Lehan, 1970: 113). Therefore, from the point of view of Freudian theory, Gatsby's painful life starts when he lost his love, Daisy Buchanan, who is "the first nice girl he had ever known" (Fitzgerald, 1996: 177). For Gatsby, "when she is lost forever, the world changes" (Lehan, 1970: 112), and "after the first love, there is no other" (Callahan, 1972: 21). The idea of loss has become one of the major themes that Fitzgerald explores, and Gatsby's loss is not even the primary case. "The psychological resistances Fitzgerald encountered while creating Gatsby are not surprising, since Gatsby embodied so many of the most painful experiences, fears, and desires of Fitzgerald's own life" (Stavola, 1979: 125). Furthermore, "Gatsby is among the handful of Fitzgerald characters who never doubt their resolve. Typically, protagonists must cede to failure and accept the illusoriness of their goal" (Curnutt, 2007: 54).

Since Gatsby loses his love, he "tries to live in a world where past, present, and future are all one" (Stavola, 1979: 131) because only in that way can he relive his past life and restore all his memories. It is clearly seen from the novel that the loss of Daisy seems to make him become another man in a different world where he is not aware of the time frame. What is more, "it is not just Daisy Gatsby wants but something beyond her: he wants that moment when life seemed equal to his extraordinary capacity to wonder, and that moment is indissolubly wedded to Daisy herself, to materiality" (Moyer, 1972: 218). Moyer (1972: 218) also suggests that "Gatsby's transcendentalism, of course, is not only tainted by materialism, it is revealed as disastrously circular since it seeks by embracing the future to regain and freeze that instant in the past when Daisy seemed equal to the demands of Gatsby's transcendental imagination".

Almost five years! There must have been moments even that afternoon when Daisy tumbled short of his dreams - not through her own fault, but because of the colossal vitality of his illusion. It had gone beyond her, beyond everything. He had thrown himself into it with a creative passion, adding to it all the time, decking it out with every bright feather that drifted his way. No amount of fire or freshness can challenge what a man can store up in his ghostly heart. (Fitzgerald, 1996: 116)

The passage above clearly shows Gatsby's "transcendental imagination" and "the colossal vitality of his illusion" from which he creates his imaginative world. His illusion makes him become a man "with a creative passion" and then it "drifted his way". It is no doubt true that what Moyer treats as "transcendental" illusion can in fact be seen in Freudian terms as psychological loss from which Gatsby never recovers during his life.

Gatsby seems to be unconscious of the changes in his life as he tries to live in his own fantasy world; in other words, it is a kind of escapism. Gatsby lives alone with just some servants in his colossal mansion. Drawing from Freudian theory, we can say that Gatsby tries to maintain his own loneliness. He wants to stay away from people and real situations in which he just feels emptiness. That is why Gatsby is there, alone, in West Egg, just to be near the woman he longs to meet and win her again, "for if Gatsby cannot seal the hole in time, cannot buy back the past, he cannot commit himself to the future" (Lehan, 1970: 110). Evidently, Gatsby creates his own world of imagination where he can reverse the time frame and find the idealized object of love for himself.

Gatsby's loneliness is depicted when Nick first sees Gatsby: "he was content to be alone- he stretched out his arms toward the dark water in a curious way" (Fitzgerald, 1996: 26). We also once see the action of stretching out his hand when he lost Daisy. When he goes along the streets in Louisville, "he stretched out his hand desperately as if to snatch only a wisp of air, to save a fragment of the spot that she [Daisy] had made lovely for him" (Fitzgerald, 1996: 183). This action shows that at that time Gatsby is unaware of what is actually happening to him in the real world. Gatsby does not want to believe the reality that Daisy has left him alone after they share many happy memories. Drawing on Freudian theory, one can say the image of a Gatsby who "stretched out his arms toward the dark water" (Fitzgerald, 1996: 26) may symbolize the subconsciousness poised against reality. He is not aware of the real world he is living in, and his existence is based on what destroyed his hope. Gatsby feels so tiny and so lonely in this world. The image of "the dark water" brings out a special symbol. Freudian theory suggests it may be used to symbolize rebirth and wishing for another life. 
Furthermore, this dark water may be used as a dark mirror of his own mind. It may be called the latent content in the story, warning him and readers that the lost experience from his past life will remain with him until his death.

The fantasy world of Gatsby is reflected in the way he holds luxurious parties "through the summer nights" (Fitzgerald, 1996: 47): "in his blue gardens men and girls came and went like moths among the whispering and the champagne and the stars" (Fitzgerald, 1996: 47). This description of the party makes us think it must be happening in a different world, a fantasy world that he creates for himself. "Gatsby's vision maintains its gigantic unreal stature. It imposes a rhythm on his guests which they accept in terms of their own tawdry illusions, having no conception of the compulsion that drives him to offer them the hospitality of his fabulous wealth" (Bewley, 1954: 42). Hence, ironically, almost all people at his luxurious parties are uninvited and nobody seems to know him well: "they came and went without having met Gatsby at all, came for the party with simplicity of heart that was its own ticket of admission" (Fitzgerald, 1996: 50). In other words, the guests just come for pleasure, not caring much about their host. In return, Gatsby holds these parties just for the purpose of seeing his love again. He idealizes his past romantic affair, which seems to be his sole source of meaningfulness at this moment.

Gatsby watches the uninvited guests "standing alone on the marble steps and looking from one group to another with approving eyes" (Fitzgerald, 1996: 61). It is very interesting that "Fitzgerald does not actually let us meet Gatsby face to face until he has concretely created his fantastic world of Gatsby's vision" (Bewley, 1954: 40). Gatsby does not care about anything around him because he "expected her [Daisy] to wander into one of his parties, some night" (Fitzgerald, 1996: 95). His purpose is to meet his love someday because he knows clearly that "Daisy would be just across the bay" (Fitzgerald, 1996: 95). Gatsby has nurtured his hope since he lost his idealized woman five years before, and "it is Gatsby's ordeal that he must separate the foul dust that floated in the wake of his dream from the reality of the dream itself" (Bewley, 1954: 42). He [Gatsby] had waited five years and bought a mansion where he creates for himself a chance to meet Daisy someday.

Nick emphasizes that "he [Gatsby] was a person of some undefined consequence" (Fitzgerald, 1996: 77). It is supposed that Nick may realize that there is something unusual in Gatsby's life or something that makes Gatsby's life unreal. There is also Nick's discovery that the past cannot be "possessed"; he had watched Gatsby searching for a past "that had not even had a momentary existence, that was the invention of his imagination" (Miller, 1964: 34). Gatsby, "who mistakenly believes that one can buy back the past" (Lehan, 1970: 113), never wants to accept the fact that he lost Daisy forever. In terms of Freudian theory, it is once again Gatsby resisting the time frame: he wants to replace his traumatized reality with a pre-trauma fantasy. Gatsby lives by pushing himself into the past and pre-dating his trauma. The reason is that he cannot find happiness and meaningfulness in his present life, and therefore he confesses details of his life to Nick.

So I [Gatsby] thought you [Nick] ought to know something about me. I didn't want you to think I was just somebody. You see, I usually find myself among strangers because I drift here and there trying to forget the sad thing that happened to me. (Fitzgerald, 1996: 81).

Furthermore, he also describes himself, rather ridiculously, as "a young rajah in all the capitals of Europe-Paris, Venice, Rome - collecting jewels, chiefly rubies, hunting big game, painting a little, things for myself only, and trying to forget something very sad that had happened to me long ago" (Fitzgerald, 1996: 79). He wants to make Nick believe that he is not an invisible man in this world, and "he was liable at the whim of an impersonal government to be blown anywhere about the world" (Fitzgerald, 1996: 179). He tries to convince Nick that he was just drifting and being a self-made man because of the very "sad thing", and he wants to change the horrible past. He wants to have Nick share his feelings as well as his exaggerated, romanticized story. However, this just proves that he is sharing his fantasies with Nick and his ghostly broken heart shows us he is forever a man of the actual traumatic past.

Miller (1964: 38) argues that "the reality is embodied in Gatsby; and as opposed to the hard, tangible illusions, the reality is a thing of spirit, a promise rather a possession of a vision". Gatsby wants to make his life revert to the time before he went off to the army five years ago, because in such a world he has a lover who "used to be able to understand him" (Fitzgerald, 1996: 133). Gatsby wants to keep that romantic moment forever, so "he talked a lot about the past", and "he wanted to recover something, some idea of himself perhaps, that had gone into loving Daisy [and] his life had been confused and distorted since then" (Fitzgerald, 1996: 133). According to Callahan (1972: 20), "Gatsby and Daisy simply are, one to the other. Myth and personality harmonize the same theme: one's deepest context must be other human beings". It is no doubt the case that Gatsby just lives his own life by nurturing the good memories of the past and he never fully recovers from his illusory dream.

According to Freudian theory, unfortunately, he has never fully faced the real trauma that happened to him. 
Undoubtedly, all his later actions just show he never believes in the fact of not having Daisy, and he wants to change his past. His memories about the past seem to make him feel alive and constitute the happiest and most important event in his life, the time when he won Daisy's heart. Loss of a relationship is the trauma of the horrible past that he has never recovered from. For Gatsby, "without Daisy, he is nothing; he is as worthless as the bonds passed illegally over the counter of his Chicago drugstore after his death" (Callahan, 1972: 21). The traumatized narrator echoes all Gatsby's words and reflects on "something - an elusive rhythm, a fragment of lost words, that I [Nick] had heard somewhere along time ago..., and all I [Nick] had almost remembered was uncommunicable forever" (Fitzgerald, 1996: 134).

\section{Conclusion}

Gatsby "had lost the old warm world, paid a high price for living too long with a single dream" (Fitzgerald, 1996: 194). While standing outside the Gatsby mansion, looking across the bay, Nick realizes that Gatsby's death, like his life, was a product of an elusive, outlived subconscious illusion. Despite all his efforts, Gatsby is unable to disown his past, and he continually suffers in the world of trauma. Gatsby evidently suffers from the trauma that he had in the past when his relationship with Daisy was broken and he really wants to recapture their happy moments by recycling and mixing past events with present ones, and to jump back into a created past with illusory emotions. In his blind pursuit of wealth, status, and success, Gatsby follows a dream that ultimately becomes a nightmare. Undoubtedly, Gatsby has experienced a traumatic event in the past and a traumatic neurosis keeps him trapped in a fantasy world forever.

\section{References}

Bewley, M. Scott Fitzgerald's Criticism of America. Lockridge, 37-53.

Breuer, J., \& Freud, S. (1893, 2001). On the Psychical Mechanism of Hysterical Phenomena: Preliminary Communication. The Standard Edition of the Complete Psychological Works of Sigmund Freud (Vol. II). London: Vintage.

Callahan, J. F. (1972). The Illusions of a Nation. Urbana, Chicago: University of Illinois Press.

Chase, R. The Great Gatsby. Hoffman, 297-302.

Curnutt, K. (2007). The Cambridge Introduction to F. Scott Fitzgerald. Cambridge: Cambridge University Press. http://dx.doi.org/10.1017/CBO9780511611032

Donaldson, S. (Ed.). (1984). Critical Essays on F. Scott Fitzgerald's The Great Gatsby. Boston: G.K Hall.

Fitzgerald, F. S. (1996). The Great Gatsby. Rpt. of 1925 Scribner's ed. Tokyo: Hon-No-Tomosha Publishers.

Forter, G. (2007). Freud, Faulkner, Caruth: Trauma and the Politics of Literary Forms. Narrative, 15(2), October 2007, 259-285. http://dx.doi.org/10.1353/nar.2007.0022

Freud, S. (1917, 2001). Introductory Lectures on Psycho-Analysis. The Standard Edition of the Complete Psychological Works of Sigmund Freud (Vol. XVI). London: Vintage.

Freud, S. (1920, 2001). Beyond the Pleasure Principle. The Standard Edition of the Complete Psychological Works of Sigmund Freud (Vol. XVIII). London: Vintage.

Hoffman, F. J. (Ed.). (1962). The Great Gatsby: A Study. New York: Charles Scribner's Sons.

Lehan, R. Focus on F. Scott Fitzgerald's The Great Gatsby. Madden, 106-14.

Lockridge, E. (Ed.). (1968). Twentieth Century Interpretation of The Great Gatsby. Eanglewood Cliffs, NJ: Prentice-Hall.

Luckhurst, R. Mixing Memory and Desire: Psychoanalysis, Psychology, and Trauma Theory. Waugh, 497-507.

Madden D. (Ed.). (1970). American Dreams, American Nightmares. Carbondale: Southern Illinois University Press.

Miller, J. E. Boats against the Current. Lockridge, 19-36.

Moyer, K. W. The Great Gatsby: Fitzgerald's Meditation on American History. Donaldson, 215-228.

Pelzer, L. C. (2000). Student Companion to F. Scott Fitzgerald. Westport, Connecticut: Greenwood Press.

Stavola, T. J. (1979). Scott Fitzgerald: Crisis in an American Identity. London: Vision Press Limited.

Troy, W. Scott Fitzgerald - The Authority of Failure. Hoffman, 224-31.

Waugh, P. (Ed.). (2006). Literary Theory and Criticism. New York: Oxford University Press. 